\title{
Caspase function in programmed cell death
}

\author{
S Kumar, ${ }^{*, 1,2}$
}

The first proapoptotic caspase, CED-3, was cloned from Caenorhabditis elegans in 1993 and shown to be essential for the developmental death of all somatic cells. Following the discovery of CED-3, caspases have been cloned from several vertebrate and invertebrate species. As reviewed in other articles in this issue of Cell Death and Differentiation, many caspases function in nonapoptotic pathways. However, as is clear from the worm studies, the evolutionarily conserved role of caspases is to execute programmed cell death. In this article, I will specifically focus on caspases that function primarily in cell death execution. In particular, the physiological function of caspases in apoptosis is discussed using examples from the worm, fly and mammals. Cell Death and Differentiation (2007) 14, 32-43. doi:10.1038/sj.cdd.4402060; published online 3 November 2006

Caspases are cysteinyl aspartate proteinases (cysteine proteases that cleave their substrates following an Asp residue). The first known member of the caspase family was caspase-1, initially known as interleukin-1 $\beta$-converting enzyme (ICE), an enzyme required for the maturation of IL $1 \beta .^{1,2}$ In 1993, the Caenorhabditis elegans cell death gene ced-3 was cloned and its product was found to be similar to ICE and a developmentally regulated protein Nedd2 (now called caspase-2). ${ }^{3-6}$ In subsequent years, a number of caspases have been cloned from various mammalian and nonmammalian species. Eleven caspases have been described in human, 10 in mouse, four in chicken, four in zebrafish, seven in Drosophila melanogaster and four in C. elegans. ${ }^{7}$ As discussed in other review articles in this issue of Cell Death and Differentiation, many of the cloned caspases, including caspase-1, do not have a role in apoptosis execution, whereas some caspases have dual functionality having roles both in apoptotic and nonapoptotic signalling. In this article, I focus primarily on caspases that either have a clearly defined function in apoptosis or have an implied function in cell death pathways. Given that there is much in common in the apoptotic function of caspases from various model organisms, I have discussed here work from $C$. elegans, $D$. melanogaster and mammals.

\section{Two Types of Apoptotic Caspases}

Almost all healthy cells contain several caspases as inactive precursors, often called caspase zymogens. Although caspase zymogens contain a small amount of catalytic activity, they are kept in check by a variety of regulatory molecules. Upon receiving an apoptotic signal, the caspase zymogens undergo proteolytic processing to generate two subunits that comprise the active enzyme..$^{8,9}$ The cleavage of the zymogen is not always an obligatory requirement for caspase activation, but all activated caspases can be detected as cleaved fragments in apoptotic cells. ${ }^{8,9}$ The structural studies predict that the mature caspase is a heterotetramer, composed of two heterodimers derived from two precursor molecules (see review by Bao and Shi in this issue). In addition to the regions that give rise to the two subunits, procaspases contain $\mathrm{N}$-terminal prodomains of varying lengths. Based on the length of the prodomain, caspases can be divided into two groups: those that have a relatively long prodomain, and those containing a short prodomain. $^{8,9}$ The long prodomains in many caspases consist of specific protein-protein interaction domains that play a crucial role in caspase activation. ${ }^{8,9}$ These domains mediate recruitment of the procaspase molecules to specific death signalling complexes, leading to their autocatalytic activation, by mechanism(s), the precise details of which are still a matter of some debate, but often termed 'proximity-induced' activation. 8,9 The caspases that get activated via recruitment to signalling complexes are known as the initiator caspases, as they provide a link between cell signalling and apoptotic execution (Figure 1). The main initiator caspases are caspase-2, -8, -9 and -10 in mammals and Drosophila Nedd2-like caspase (DRONC) in Drosophila. These caspases either contain a caspase recruitment domain (CARD), as in caspase-2, -9 and DRONC, or a pair of death effector domains (DEDs), as in caspase-8 and -10 (Figure 2). These domains bind similar motifs in adaptor proteins (Table 1). The caspases lacking a long prodomain lack the ability to self-activate and require cleavage by activated initiator caspases. ${ }^{8,9}$ Given that most of the cellular substrates are cleaved by these downstream caspases (see

\footnotetext{
${ }^{1}$ Hanson Institute, Institute of Medical and Veterinary Science, Adelaide, SA, Australia and ${ }^{2}$ The Department of Medicine, University of Adelaide, Adelaide, SA, Australia *Corresponding author: S Kumar, Hanson Institute, Institute of Medical and Veterinary Science, PO Box 14, Rundle Mall, Adelaide, SA 5000, Australia.

Tel: + 6188222 3738; Fax: + 6188222 3139; E-mail: sharad.kumar@imvs.sa.gov.au

Keywords: DRONC; DRICE; Apaf-1; cytochrome $C$; apoptosome; caspase activation; caspase function

Abbreviations: PCD, programmed cell death; DIAP1, Drosophila inhibitor of apoptosis protein 1; DED, death effector domain; CARD, caspase recruitment domain; DRONC, Drosophila Nedd2-like caspase; MEFs, mouse embryonic fibroblasts; IAP, inhibitor of apoptosis protein; RNAi, RNA interference; KO, (gene) knockout; DKO, double knockout; $\mathrm{BH}, \mathrm{Bcl}-2$ homology (domain); CNS, central nervous system; RHG, REAPER/HID/GRIM (domain); EcR, ecdysone receptor; Usp, ultraspiracle Received 04.9.06; revised 09.10.06; accepted 09.10.06; Edited by P Vandenabeele; published online 03.11.06
} 

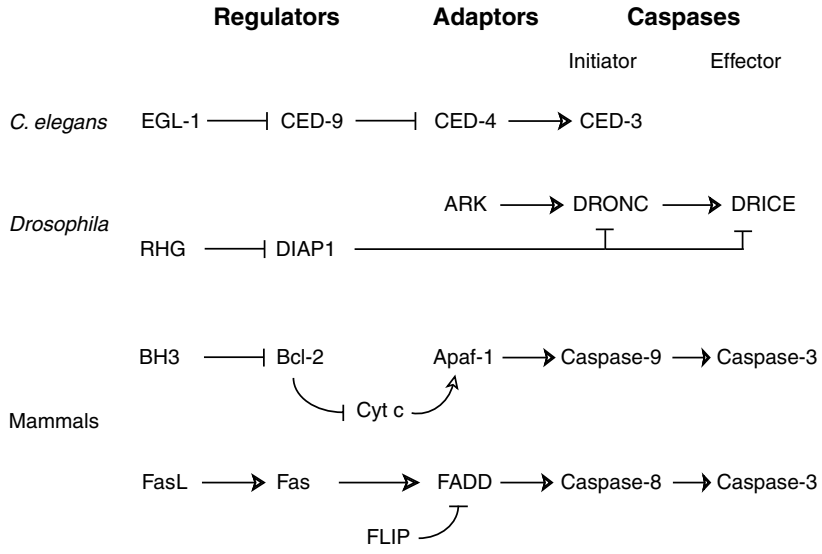

Figure 1 Evolutionary conservation of the caspase activation pathways. Various regulators that initiate caspase activation or keep caspase activation in check, adaptors that mediate activation of initiator caspases, the initiator and effectors caspases, in Caenorhabditis elegans, Drosophila melanogaster and mammals are shown

\begin{tabular}{|c|c|c|c|}
\hline \multicolumn{4}{|c|}{ C. elegans } \\
\hline CARD & Large & Small & CED-3 \\
\hline \multicolumn{4}{|c|}{ Drosophila } \\
\hline DED & Large & Small & DREDD \\
\hline CARD & Large & Small & DRONC \\
\hline Ser/Thr Rich Domain & Large & Small & STRICA \\
\hline & Large & Small & DRICE, DCP-1 \\
\hline & lamma & & \\
\hline DED & Large & Small & Caspase-8/-10 \\
\hline CARD & Large & Small & Caspase-2/-9 \\
\hline & Large & Small & Caspase-3/-6/-7 \\
\hline
\end{tabular}

Figure 2 The initiator and effector caspases in C. elegans, Drosophila and mammals. Only caspases with potential or demonstrated role in apoptosis are shown. The small and large subunits, and the protein-protein interaction motifs (such as CARD and DED) are shown. Note that the long prodomain in STRICA does not contain any protein-protein interaction motif(s). The relative lengths of various domains and subunits are not drawn to size and only serve as a guide here to demonstrate the various types of apoptotic caspases found in C. elegans, Drosophila and mammals

review by Timmer and Salvesen in this issue), these caspases are often called the effector caspases. The key effector caspases in mammals include caspases-3, -6 and -7 , and in Drosophila DRICE.

\section{CED-3, the Death Caspase in C. elegans}

Although there are four caspase-like proteins in C. elegans, CED-3 is the only one that has been shown to be required for apoptosis. ${ }^{10,11}$ It is a CARD-containing caspase that acts both as initiator and effector caspase. EGL-1, a Bcl-2 homology (domain) $(\mathrm{BH}) 3-$ only protein, CED-3 and CED-4, the adaptor
Table 1 Various adaptors for initiator caspases and the domains that mediate caspase/adaptor interactions

\begin{tabular}{lll}
\hline Caspase & Adaptor & $\begin{array}{l}\text { Domain } \\
\text { mediating } \\
\text { interaction }\end{array}$ \\
\hline CED-3 & CED-4 & CARD \\
DRONC & ARK & CARD \\
DREDD & dFADD & DED \\
Caspase-2 & RAIDD & CARD \\
Caspase-8 & FADD & DED \\
Caspase-9 & Apaf-1 & CARD \\
Caspase-10 & FADD & DED \\
\hline
\end{tabular}

that mediates CED-3 activation, are all essential for all developmentally programmed cell death (PCD) in the worm and loss of function mutants of egl-1, ced-4 and ced-3 result in the survival of all 131 somatic cells that are destined to die. ${ }^{10,12}$ The Bcl-2-like protein CED-9 by contrast prevents cell death by blocking the activation of CED-3 (Figure 1). Recent structural and biochemical data demonstrate that CED-3 is activated by a tetrameric CED-4 complex (apoptosome) that is prevented from assembling by interaction with CED-9 until EGL-1 sequesters CED-9 away. ${ }^{13}$ In healthy cells, CED-4 is a dimer directly bound to CED-9, and presumably this interaction prevents CED-4 activation by tetramerization. $^{13}$ The elevated levels of EGL-1, primarily regulated by transcription in response to developmental cues, allow sequestration of CED-9 and release of CED-4. Following the release from CED-9, two CED-4 dimers form the active tetramer that recruits and facilitates CED-3 activation. ${ }^{12,13}$ Like mammalian APAF-1 and Drosophila ARK (see below), CED-4 is a member of the P-loop ATPase family that comprises a CARD followed by a nucleotide-binding/oligomerisation domain, and a second conserved helical domain. ${ }^{12,13}$ The CARDs in the CED-4 apoptosome directly bind the CARD of CED-3 facilitating proximity-induced autoactivation of CED-3. ${ }^{12,13}$

\section{Cell Death Caspases in Drosophila}

There are seven caspases in Drosophila named DCP-1, DREDD/DCP-2, DRICE, DRONC, DECAY, DAMM and STRICA/DREAM. ${ }^{14-20}$ Similar to mammalian caspases, Drosophila caspases can be divided into initiator and effector caspases based on their prodomains. ${ }^{21}$ The caspases DREDD, DRONC and STRICA contain long amino-terminal prodomains, whereas DCP-1, DRICE, DECAY and DAMM have short prodomains (Figure 2). DREDD contains two DEDs in its prodomain region, whereas DRONC is the only CARD-containing caspase in flies. ${ }^{15,17}$ STRICA, the third fly caspase with a long amino-terminal region contains a Ser/Thrrich prodomain that lacks any CARD or DED-like structures. ${ }^{20}$ The significance and function of this unusual prodomain in STRICA is not currently known, and similar prodomains have not been reported in mammals. DCP-1 and DRICE are highly homologous to each other, whereas DECAY is the next closest relative of DRICE and DCP-1. ${ }^{21}$ All these three caspases share a high degree of homology with the mammalian caspase-3. ${ }^{21}$ Despite the presence of two DEDs in its prodomain, DREDD shows more overall sequence 
homology to the CARD-containing mammalian caspase-2, than to the DED-containing caspase- $8 .^{21}$ The primary aminoacid sequence of DRONC is also most similar to caspase-2, rather than its predicted functional homologue caspase-9. ${ }^{21}$ DAMM and STRICA are distantly related to other fly caspases, and despite the difference in the length of their prodomains, share highly related caspase domains. ${ }^{19-21}$

\section{Functions of Fly Caspases}

DREDD. An initial report suggested that DREDD functions in cell death. ${ }^{15}$ This conclusion was based on expression analysis and overexpression studies that showed that the mRNA for dredd accumulates in preapoptotic cells, and that signalling by RPR, HID and GRIM results in processing of DREDD to its active form in transfected Drosophila S2 cells. ${ }^{15}$ Additional evidence for a function of DREDD in apoptosis came from the observation that heterozygosity at the dredd locus suppresses cell death induced by the ectopic expression of rpr, grim and hid in transgenic models, indicating that the concentration of DREDD may be a ratelimiting step in apoptosis. ${ }^{15}$

However, subsequent genetic data from the analysis of dredd mutants suggest that the primary function of DREDD is in innate immune response by regulating the activation of RELISH, a member of the NF- $\kappa$ B family. ${ }^{22}$ Flies mutated at the dredd locus fail to induce the synthesis of antimicrobial peptides and are highly susceptible to infection by Gramnegative bacteria. ${ }^{22}$ Recent data indicate that DREDD and its adaptor $\mathrm{dFADD}^{23}$ are required for the activation of IKK and JNK, components of the Drosophila antibacterial immunity pathway. ${ }^{24}$ dFADD and DREDD have also been shown to participate in spermatid individualization in Drosophila; ${ }^{25}$ however, their exact function in that process remains unknown.

DRONC. DRONC was first cloned as a caspase with most homology to mammalian caspase-2 (Nedd2). ${ }^{17}$ As it is the only CARD-containing caspase in fly, it can be regarded as the true CED-3/caspase-9 orthologue. Indeed, a number of recent studies establish DRONC as the main (and perhaps only) initiator caspase in Drosophila. ${ }^{26-32}$ Earlier studies had shown that the heterozygosity at the dronc locus or the expression of a catalytically inactive DRONC mutant suppress the ablated eye phenotype caused by the overexpression of rpr, hid and grim, consistent with the idea that DRONC is a downstream effector in the pathways mediated by these DIAP1 antagonists (see below). ${ }^{33-35}$ More recent studies using dronc-null animals have confirmed these findings and also shown that to suppress HIDinduced apoptosis, both copies of dronc need to be inactivated. ${ }^{26-30}$ Loss of DRONC function by RNAi results in almost complete loss of apoptosis in embryos, indicating that DRONC is required for most PCD during embryogenesis. ${ }^{34}$ Similarly, in the germline dronc mutant embryos, most PCD is absent and these embryos fail to hatch. ${ }^{28}$ Both in vitro and in vivo studies show that DRONC is essential for most PCD in larval tissues and apoptosis induced by cytotoxic agents, including $X$ - and $\gamma$-irradiation. ${ }^{26-35}$

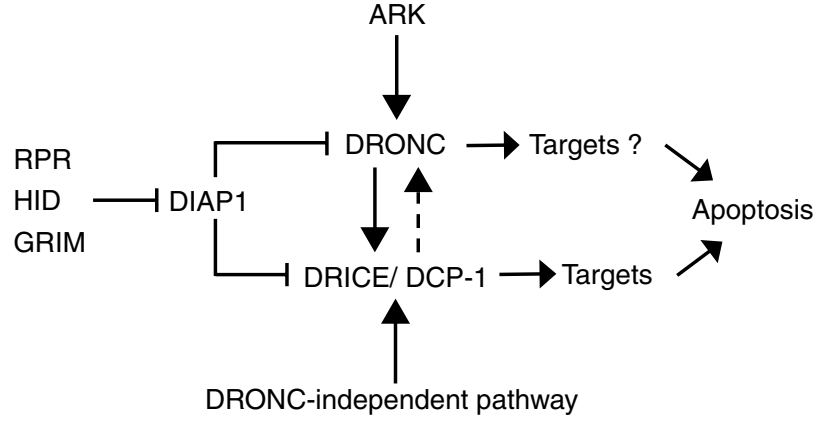

Figure 3 Pathways of caspase activation in Drosophila. The canonical caspase activation pathway in Drosophila involves removal of DIAP1 from DRONC via the RPR, HID and GRIM proteins that bind and facilitate autoubiquitination of DIAP1. Removal of DIAP1 allows DRONC to be activated in an ARK-dependent manner. Activated DRONC activates downstream effector caspases such as DRICE and DCP-1. In some cases, such as in larval midguts, effector caspases can also be activated by an unknown mechanism that is independent of DRONC

DRONC ablation also blocks apoptosis induced by the loss of DIAP1, suggesting that DRONC mediates cell death by signals that lead to DIAP1 degradation. ${ }^{36}$

dronc is upregulated by the steroid hormone ecdysone, which mediates the histolysis of larval tissues during metamorphosis, and loss of dronc delays the removal of larval salivary glands. ${ }^{17,26,29}$ Furthermore, in cultured cells, dronc ablation by RNA interference (RNAi) inhibits cell death induced by ecdysone. ${ }^{37,38}$ However, surprisingly, midgut removal and downstream caspase activation in larval midguts occur normally in dronc mutant animals, ${ }^{26}$ suggesting that alternative ways of activating effector caspases exists in some cases (Figure 3). Gene expression and promoter analysis indicate that the dronc gene is regulated by the heterodimeric nuclear receptor EcR/Usp (ecdysone receptor/ultraspiracle) directly in response to ecdysone and also via the ecdysoneinduced transcription factor BR-C. ${ }^{37,38}$ CARMER, the fly homologue of the mammalian CARM1 histone methyl transferase, is also recruited to the dronc promoter via the EcR/Usp complex and positively regulates ecdysone-induced dronc expression. ${ }^{39}$ dronc promoter is spatially and temporally regulated during Drosophila development. ${ }^{40}$ Therefore, the levels of DRONC may determine the cell survival/death of specific cell populations during development. Although precisely how dronc expression is regulated is not understood, complex regulation by various transcription factors and chromatin modification/remodelling are likely to contribute to this process. ${ }^{41}$

Although DRONC is clearly a caspase which efficiently cleaves synthetic substrates such as VDVAD, and downstream caspases DRICE and DCP-1, following an Asp residue, recombinant DRONC expressed in Escherichia coli can autoprocess following a Glu residue in the $P_{1}$ position. ${ }^{35}$ This unusual substrate cleavage activity of DRONC may be attributed to an atypical sequence of the catalytic site. ${ }^{17}$ The known targets of DRONC include effector caspases DRICE and DCP-1 and removal of DRONC inhibits the processing of these caspases, suggesting that DRONC is required for downstream caspase activation. ${ }^{31,32,42}$ DRONC cleaves and activates DRICE and DCP-1 at a TETD sequence. ${ }^{31,35}$ In addition to its essential function in cell death, DRONC has also 
been implicated in several nonapoptotic functions, ${ }^{25,30,32}$ and it appears that low levels of spatially regulated activation is required for its nonapoptotic roles, whereas high level activation leads to apoptosis. ${ }^{43}$

DRICE. DRICE is the most abundant and widely expressed effector caspase in Drosophila. ${ }^{16,21}$ It is also most similar to mammalian caspase- 3 and exhibits similar substrate specificity, with an optimal activity on caspase-3 substrate DEVD. ${ }^{16,21}$ In most cases, DRICE is activated by DRONC and RNAi and genetic studies have shown that loss of dronc function severely impairs DRICE activation. ${ }^{27,28,42}$ However, DRONC-independent effector caspase activation (presumably DRICE) has also been noted in larval midguts. ${ }^{27}$ A systematic in vivo RNAi study demonstrated that DRONC, DRICE, STRICA and DECAY are rate limiting for apoptosis. $^{36}$ This work also suggested that HID-mediated apoptosis requires STRICA, DECAY, DRONC and DRICE, whereas apoptosis induced by DIAP1 removal is primarily dependent on DRONC and DRICE. ${ }^{36}$ Three laboratories have recently published studies of independently generated drice mutants. ${ }^{30,44,45}$ The analyses of these mutants suggest that drice acts genetically downstream of RPR, HID, GRIM and DIAP1 and is required for most cell deaths that occur during development. Additionally, drice-null cells are resistant to stress and irradiation-mediated cell death. However, around $10 \%$ of animals survive in the absence of DRICE and in some tissues cell death can occur normally. Studies with a drice/dcp-1 double mutant suggest that some cells require DRICE for apoptosis, whereas in other DRICE and DCP-1 play a somewhat redundant function. ${ }^{30,45}$

Like dronc, drice expression is also regulated by ecdysone in salivary glands during metamorphosis. ${ }^{46}$ RNAi studies in an ecdysone-responsive Drosophila cell line and in salivary glands suggest that drice is necessary for efficient apoptosis induced by ecdysone. ${ }^{36,46}$ However, in drice mutants, salivary glands seem to undergo normal cell death, ${ }^{44}$ suggesting possible functional redundancy/compensation in vivo. In I(2)mbn cells, drice expression appears to be specifically controlled by the ecdysone-regulated transcription factor BR-C. ${ }^{46}$ DRICE also seems to contribute to the nonapoptotic process of spermatid differentiation. ${ }^{45}$ The known targets of DRICE include lamin DmO, DIAP1, DRONC and baculovirus p35. ${ }^{21,47}$ In mammals, caspase-3 cleaves inhibitor of caspase activated DNase (ICAD), resulting in the release and activation of CAD, which mediates DNA fragmentation. ${ }^{48}$ Similarly, DRICE mediates cleavage of Drosophila ICAD (dICAD). ${ }^{49}$ However, unlike in mammals, caspase-mediated CAD cleavage is also necessary for dCAD activation. ${ }^{49}$

DCP-1. DCP-1 was the first cloned Drosophila caspase. ${ }^{14}$ Initial studies reported that $d c p$-1-null mutations are larval lethal, with larvae carrying melanotic tumors. ${ }^{14}$ The mutants also had other apparent developmental abnormalities and female flies carrying the $d c p-1^{-}$germline clones were sterile owing to a defect in the transfer of nurse cell cytoplasmic contents to developing oocytes. ${ }^{50}$ Later studies revealed that these phenotypes were owing to the loss of function of an outlying gene pita, rather than $d c p-1 .^{51}$ The specific $d c p-1$ null animals are viable, develop normally and do not show any apparent phenotype, suggesting that this caspase is not essential for any developmental cell death and is functionally redundant. $^{30,44,45}$ Interestingly, the study of drice/dcp-1 double mutant reveals that some cells strictly require DRICE for apoptosis, whereas other cells require either DRICE or DCP $-1 .{ }^{45}$ For example, the embryos and larval eye discs from drice/dcp-1 double mutants show significantly reduced cell death when compared to drice mutants. ${ }^{45}$ Recently, Kondo et al. ${ }^{30}$ also reported that drice/dcp-1 double mutants essentially phenocopy dronc mutants, suggesting that both these effector caspases act downstream of DRONC and have some overlapping function. In vitro RNAi data suggest that specific ablation of DCP-1 from I(2)mbn cells significantly reduces the rate of ecdysone-induced apoptosis. ${ }^{46}$ Thus, although it seems that most cell deaths can occur in the absence of DCP-1, this caspase may yet contribute to the efficiency of cell death execution, at least in some cell types. Given its close similarity with DRICE, DCP-1 substrate specificity mimics that of DRICE cleavage specificity and both these caspases are likely to have similar substrates. ${ }^{21}$

DECAY, DAMM and STRICA. DECAY is also related to DRICE, DCP-1 and mammalian caspase-3 and has the ability to cleave DEVD in vitro. ${ }^{18}$ Ectopic expression of DECAY has a weak apoptotic effect in mammalian cells, ${ }^{18}$ but its function in Drosophila cell death pathways is somewhat less clear at present. Recently, the Miura laboratory generated a decay mutant and found that decay mutants are viable and fertile and do not show any obvious abnormalities. ${ }^{30}$ Furthermore, the authors state that the developmental PCD occurred normally in decay mutants, suggesting that DECAY function is redundant, at least during development.

The functions of DAMM and STRICA, both of which can induce cell death in vitro to some extent, are not fully understood, as specific mutants for these caspases are currently unavailable. Ectopic overexpression of damm or strica in the Drosophila eye results in a rough eye phenotype, and the expression of these caspases sensitises cells to apoptosis. ${ }^{19,20}$ As mentioned earlier, strica RNAi results in delayed removal of larval salivary glands, ${ }^{36}$ consistent with the observation that strica transcript is upregulated in salivary glands prior to their histolysis. ${ }^{52}$ These observations suggest that, along with DRONC, DRICE and DCP-1, STRICA may also contribute to the efficient PCD of salivary glands during Drosophila metamorphosis.

\section{Activation of Fly Caspases}

The main regulator of caspase activation (and caspase activity), and thus cell surival/apoptosis in Drosophila is DIAP1 (Drosophila inhibitor of apoptosis protein 1). ${ }^{53,54}$ Unlike in mammals, the Bcl-2 family of proteins (two in Drosophila ${ }^{55,56}$ ) seem to play a less important role (if any) in regulating caspase activation in flies. DIAP1 binds and inhibits both the initiator caspase DRONC and effector caspases DRICE and DCP-1 (see review by Callus and Vaux in this issue). DIAP1 consists of two BIR (Baculoviral inhibitor of apoptosis protein (IAP) repeat) domains and a RING type of 
ubiquitin-ligase domain. BIR1 interacts with DRICE, whereas BIR2 binds DRONC. DIAP1 mutant embryos and cells where DIAP1 has been ablated show spontaneous caspase activation and apoptosis. ${ }^{57}$ Thus, it seems that in healthy cells DIAP1 is bound to DRONC, preventing its interaction with ARK. Upon receiving an appropriate death signal, RPR, HID and GRIM bind DIAP1 resulting in its autoubiquitination, followed by proteasome-dependent degradation. With the DIAP1 inhibition taken away, DRONC activation can now proceed in an ARK-dependent manner. Interestingly, unlike in mammals where Apaf- 1 requires binding to cytochrome $c$ that is released from mitochondria for its activation and oligomerzation (see review by Bao and Shi in this issue), ${ }^{58}$ ARKmediated DRONC activation can occur in the absence of cytochrome $c$ release from mitochondria. ${ }^{59}$ The trigger for DRONC activation is thus likely to be the removal of the inhibitory effects of DIAP1. This could be achieved by increasing the intracellular levels of RPR, HID or GRIM, or by elevating the concentration of DRONC and ARK, the scenarios that are seen during developmental cell death in Drosophila. $^{41}$

Loss-of-function mutations in ark block most developmentally programmed cell death, resulting in extra cells in the embryos, hyperplasia of the central nervous system and other abnormalities. ${ }^{60-62}$ ark mutants essentially phenocopy dronc mutants and show a block in the removal of larval salivary glands, but the histolysis of midgut appears normal in ark-null animals. ${ }^{60-62}$ Caspase activation is severely impaired in the absence of ARK, suggesting that ARK is required for DRONC activation. ${ }^{60}$ Structurally, ARK is more similar to its mammalian counterpart Apaf-1 than to CED-4, in that it consists of several WD40 repeats not found in CED-4. ${ }^{59}$ However, it does not require cytochrome $c$ for the formation of an apoptosome. In response to many apoptotic insults, Drosophila cells fail to show cytochrome $c$ release and extensive RNAi, expression and biochemical data show that cytochrome $c$ is not required for caspase activation and apoptosis in Drosophila cells. ${ }^{42,63-66}$ ARK can assemble into a large apoptosome complex in the presence of dATP. ${ }^{67}$ However, cytochrome $c$ is not required for the apoptosome assembly and fails to bind the complex. ${ }^{67}$ The 3D structure of the ARK complex at $18.8 \mathrm{~A}$ resolution using electron cryo-microscopy showed that eight ARK molecules assemble into an apoptosome-like particle. ${ }^{67}$ Interestingly, the ARK apoptosome is a double-ringed structure. ${ }^{67}$ Currently, the mechanism by which DRONC is recruited and activated by this apoptosome is not understood.

\section{The Mammalian Apoptotic Caspases}

In mammals, the function and regulation of caspases in cell death is complex, often complicated by the publication of conflicting data using reagents and inhibitors of dubious specificity. The data from caspase knockout (KO) animals has also been plagued by controversies, often due to the phenotypic anomalies in different genetic backgrounds of mice. This has lead to much confusion and reinterpretation of existing data and suggestions that caspases may not always be required for apoptosis. Nonetheless, caspase-2, -8, -9 and -10 are thought to be the initiator caspases, whereas caspase3 , and to a lesser extent caspase- 6 and -7 , serve as effector caspase (Figure 2; Table 2) ${ }^{8,9}$ Caspase-9 is regarded as the canonical caspase in the intrinsic mitochondrial pathway and caspase-8 as the key initiator of death receptor-mediated apoptosis. $^{8,9}$ The role of caspase-2 remains somewhat controversial and enigmatic (see below).

Caspase-9. Caspase- 9 is a key component of the mitochondrial death pathway (the intrinsic pathway) that is regulated primarily by the $\mathrm{Bcl}-2$ family and the $\mathrm{BH}-3(\mathrm{Bcl}-2$ homology domain-3)-only proteins. ${ }^{8,9}$ In this pathway, cell death signals lead to cytochrome $c$ release from the mitochondria, which binds and facilitates the formation of the septameric apoptosome that recruits and activates caspase-9. ${ }^{58,68}$ The apoptosome-bound caspase- 9 cleaves and activates caspase-3. Caspase gene $\mathrm{KO}$ in mouse emphasises the complexity of the caspase activation pathways. Depending upon the strain of mice, $\mathrm{KO}$ of caspase- 9 results in embryonic or postnatal lethality. ${ }^{69,70}$ In the mixed genetic background, the phenotypes of the casp9-/- and casp3-/- mice are quite similar suggesting that these caspases lie in the same pathway. ${ }^{69-71}$ The most profound defect in casp9 $\mathrm{KO}$ mice is hyperplasia in the brain resulting from decreased apoptosis. ${ }^{69,70}$ Defective neural tube closure in the hindbrain region and enlarged proliferation zones in the fore and midbrain result in expansion and protrusion of cranial tissues. Cells from casp9-null mice show resistance to apoptosis induced by a range of cytotoxic drugs and irradiation. ${ }^{69,70}$ Caspase-3 processing is deficient in casp9 mutant brain tissue and lysates from caspase-9-deficient thymocytes or embryonic brains are unable to process caspase- 3 even in the presence of cytochrome $c$ and dATP. This activity can be restored by the addition of in vitro translated caspase- 9 to the lysates.

As stated above, Apaf-1 (CED-4/ARK homologue) is required for caspase- 9 activation. Overall, apaf- $1 \mathrm{KO}$ animals have a phenotype similar to casp $9 \mathrm{KO}$ animals, but they additionally show a delayed removal of interdigital webbing in embryos. $^{72,73}$ Caspase-3 activation is reduced in apaf1deficient cells and mutant cells show resistance to a variety of apoptosis stimuli. ${ }^{72,73}$ Additional defects seen in apaf1 $\mathrm{KO}$ but not in casp-9-/- mutants indicate that Apaf-1 may function in developmental cell deaths that are independent of caspase- 9 activity. Interestingly, Honarpour et al. ${ }^{74}$ reported that around $5 \%$ of the apaf-1-deficient animals survive to adulthood. These animals show normal brain development, but are male sterile because of degeneration of spermatogonia. More recently, mixed background apaf-1 $\mathrm{KO}$ animals, backcrossed into C57BL/6 background for more than five times, generated fertile males in the complete absence of Apaf-1. ${ }^{75}$ When crossed with heterozygous apaf-1 females, $45 \%$ apaf-1 homozyous animals were born alive, many survived for more than eight weeks, some survived to adulthood and were fertile. ${ }^{75}$ The Apaf-1/caspase- 9 pathway also appears to be dispensable for the apoptosis of many haematopoietic lineages and loss of either caspase- 9 or Apaf1 only delays apoptosis but fails to provide clonogenic survival of cells. ${ }^{76-79}$ These data suggest that caspase-9/Apaf-1 pathway is not essential for normal animal development or cell death and the genetic background of mice is a major factor in many of the observed phenotypes. 
Table 2 A summary of studies employing loss-of-function mutations, gene knockout (KO) or RNAi to demonstrate caspase function in vivo

\begin{tabular}{|c|c|c|}
\hline $\begin{array}{l}\text { Caspase and the adaptor } \\
\text { genes }\end{array}$ & Mutant phenotype & $\begin{array}{l}\text { Physiological function from mutant analysis } \\
\text { and RNAi data }\end{array}$ \\
\hline \multicolumn{3}{|l|}{ C. elegans } \\
\hline & & somatic cells \\
\hline ced-4 (adaptor) & Same as ced-3 mutants & Similar to $c e d-3$ \\
\hline \multicolumn{3}{|l|}{ Drosophila } \\
\hline Dronc & $\begin{array}{l}\text { Pupal lethality, multiple cell death defects in } \\
\text { embryos, larvae and prepupae }\end{array}$ & $\begin{array}{l}\text { Essential for most programmed cell death (PCD) } \\
\text { during development and for stress-induced } \\
\text { apoptosis }\end{array}$ \\
\hline ark (adaptor for dronc) & Essentially similar to dronc mutants & $\begin{array}{l}\text { Essential for most developmental PCD and stress- } \\
\text { induced apoptosis }\end{array}$ \\
\hline Dredd & Normal development & $\begin{array}{l}\text { No clear function in PCD. Required for innate } \\
\text { immunity }\end{array}$ \\
\hline Strica & Specific mutants not available & strica RNAi delays larval salivary gland removal \\
\hline Drice & $\begin{array}{l}\text { Pupal lethal. About } 10-20 \% \text { animals develop to } \\
\text { adulthood. Reduced PCD in embryos, larvae and } \\
\text { prepupae }\end{array}$ & $\begin{array}{l}\text { Required for much of the developmental PCD and } \\
\text { stress-induced apoptosis. Some redundancy with } \\
\text { DCP-1 }\end{array}$ \\
\hline$d c p-1$ & Mutants are viable and fertile & $\begin{array}{l}\text { Relatively minor role in PCD that overlaps with } \\
\text { DRICE function }\end{array}$ \\
\hline drice/dcp-1 & Prepupal lethal. Phenotype similar to dronc mutants & $\begin{array}{l}\text { Some overlap in function with DCP-1. However, } \\
\text { DRICE is the predominant effector caspase in fly }\end{array}$ \\
\hline Decay & Mutants are viable and fertile & No clear function in PCD established as yet \\
\hline Damm & Specific mutants not available & Physiological function not established \\
\hline \multicolumn{3}{|l|}{ Mammals } \\
\hline caspase-2 & $\begin{array}{l}\text { Mice are viable and fertile. MEFs show some } \\
\text { resistance to killing by HS and specific drugs }\end{array}$ & $\begin{array}{l}\text { Functionally implicated in many cell death and other } \\
\text { pathways. However, the KO data do not support } \\
\text { many of the in vitro studies }\end{array}$ \\
\hline caspase-3 & $\begin{array}{l}\text { Perinatal lethal in mixed genetic background, but } \\
\text { some animals can survive to adulthood. Hyperplasia } \\
\text { in brain }\end{array}$ & $\begin{array}{l}\text { Required for neuronal cell death in mixed genetic } \\
\text { background. May play redundant function in other } \\
\text { tissues }\end{array}$ \\
\hline caspase- 6 & Normal development & No reported cell death defects in mutants \\
\hline caspase-7 & Mutants are viable and fertile & No apparent apoptotic defects in mutants \\
\hline caspase-3/-7 DKO & $\begin{array}{l}\text { Perinatal lethal. Defects in cardiac development. } \\
\text { MEFs show resistance to apoptosis }\end{array}$ & $\begin{array}{l}\text { Caspase- } 3 \text { and }-7 \text { are required for mediating } \\
\text { mitochondrial events of apoptosis }\end{array}$ \\
\hline caspase-8 & $\begin{array}{l}\text { Embryonic lethal. Defects in cardiac and T-cell } \\
\text { development. All death receptor-mediated } \\
\text { apoptosis impaired in }-/- \text { cells. Familial mutations } \\
\text { in humans associated with immunodeficiency }\end{array}$ & $\begin{array}{l}\text { Essential for apoptosis mediated by TNF family } \\
\text { members. Has nonapoptotic functions in } \\
\text { vasculature development and activation-induced } \\
\text { lymphocyte proliferation }\end{array}$ \\
\hline $\begin{array}{l}\text { FADD (adaptor for } \\
\text { caspase-8) }\end{array}$ & Essentially similar to caspase- $8 \mathrm{KO}$ mice & Essential for caspase- 8 activation \\
\hline caspase-9 & $\begin{array}{l}\text { Perinatal lethal, but some animals survive to } \\
\text { adulthood. Defects in apoptosis in the CNS. Some } \\
\text { cells resistant to stress-induced apoptosis }\end{array}$ & $\begin{array}{l}\text { Required for efficient apoptosis in some cell types. } \\
\text { Apparently not required for apoptosis in } \\
\text { haematopoietic cells }\end{array}$ \\
\hline $\begin{array}{l}\text { Apaf-1 (adaptor for } \\
\text { caspase-9) }\end{array}$ & $\begin{array}{l}\text { Essentially similar to caspase- } 9 \text { KO mice. Some } \\
\text { animals survive to adulthood }\end{array}$ & $\begin{array}{l}\text { Essential for caspase- } 9 \text { activation. May have } \\
\text { additional functions }\end{array}$ \\
\hline caspase-10 & $\begin{array}{l}\text { There is no caspase- } 10 \text { homologue in mouse. } \\
\text { Familial mutations in patients with autoimmune } \\
\text { lymphoproliferative syndrome type II }\end{array}$ & $\begin{array}{l}\text { Possibly required for apoptosis mediated by the } \\
\text { death receptors }\end{array}$ \\
\hline
\end{tabular}

Please see text for citations and references

The cytochrome $c$ knock-in mice in which the normal allele is replaced by a mutant cytochrome $c$ (known as the KA allele), which retains normal respiratory function but does not activate Apaf-1, show embryonic or perinatal lethality and a phenotype somewhat similar to apaf-1 $\mathrm{KO}$, with brain abnormalities. ${ }^{80}$ Interestingly, while the fibroblasts from the KA mice are resistant to apoptosis, their thymocytes are more sensitive to apoptosis than the apaf-1-null thymocytes. Following irradiation, KA thymocytes undergo apoptosis and caspase activation in the absence of apoptosome formation, suggesting the existence of an apoptosome-independent mechanism of caspase activation in thymocytes. ${ }^{80}$ The KA mice confirm that cytochrome $c$ is essential for Apaf-1 activation, and also provide evidence for alternative pathways of caspase activation.

Caspase-8. Caspase- 8 is an essential component of the extrinsic cell death pathways initiated by the TNF family members. ${ }^{81,82}$ In response to the activation of the death receptors of the TNF family, caspase- 8 is recruited to the death-inducing signalling complex (DISC) via binding to the adaptor protein FADD. ${ }^{81,82}$ This recruitment results in caspase- 8 activation and cell death. ${ }^{83,84}$ The loss of function of caspase-8 provides one of the clearest phenotypes to support its role in extrinsic pathway of cell death. casp $8 \mathrm{KO}$ mice are embryonic lethal around E12 with 
smaller embryos displaying impaired heart muscle development and an accumulation of erythrocytes in the abdomen and in blood vessels in the trunk. ${ }^{83}$ Excessive erythrocytosis is also seen in the liver of mutants although the mutants contain reduced haemopoetic stem cell numbers. casp8-null fibroblasts are resistant to apoptosis in response to the ligation of death-inducing TNFR family members, although cell death via the intrinsic pathway is not affected. ${ }^{83}$ These results suggest that while caspase-8 plays nonredundant roles in normal embryonic development and apoptosis mediated by the TNFR family members, it is dispensable for other apoptotic pathways. There is some evidence to suggest that the loss of human caspase- 8 leads to immunodeficiency. Chun et al. ${ }^{85}$ described a kindred with inherited caspase-8 deficiency. Individuals homozygous for the allele show defective lymphocyte apoptosis and homeostasis. Additionally, defects in their $\mathrm{T}$ and $\mathrm{B}$ cells and natural killer cells were reported. Consistent with this finding, conditional deletion of casp8 gene in mouse shows both apoptotic and nonapoptotic functions of caspase-8. ${ }^{84}$ While casp $8 \mathrm{KO}$ in hepatocytes resulted in resistance to Fasinduced apoptosis, $\mathrm{KO}$ in the bone marrow cells leads to a block in haematopoietic progenitor functional potential. Caspase- 8 is also required for macrophage differentiation and in endothelial cells for the formation of yolk sac vasculature. $^{84}$

Caspase- 8 activation requires the adaptor FADD and the study of fadd $\mathrm{KO}$ animals recapitulates this nicely. The fadd $\mathrm{KO}$ in mice is lethal around E12.5..$^{86,87}$ The fadd-deficient animals display features of delayed development, similar to the casp8 KO embryos. At E10.5, the ventricular myocardium is thinner than normal and the inner trabeculation is poorly developed, indicating that FADD plays a nonredundant role in heart development. The mutants also show abdominal haemorrhage, which is not caused by abnormal blood vessel development. The fadd-deficient mouse embryonic fibroblasts (MEFs) show resistance to apoptosis induced by TNF family members; however, apoptosis induced by the overexpression of oncogenes or by cytotoxic drugs is not affected, suggesting that the intrinsic pathway is intact. Conditional fadd $\mathrm{KO}$ data indicate that like caspase-8, FADD is required for T-cell development and peripheral T-cell homeostasis. ${ }^{88,89}$ The similarity in the phenotypes of casp 8 and fadd mutant mice suggests that FADD and caspase- 8 are essential for apoptosis mediated by many of the TNFRs, but also play context-dependent nonapoptotic functions (see article by Lamkanfi et al. in this issue).

Caspase-10. Caspase-10 is similar to caspase-8 and contains two DEDs like caspase- $8,{ }^{8,9}$ however its function in apoptosis remains a matter of considerable debate. Interestingly, there is no mouse homologue of caspase-10. Some data suggest that human caspase-10 may have a function overlapping with caspase-8 in Fas ligand-mediated cell death pathway. ${ }^{90,91}$ Similar to caspase- 8 , caspase-10 is recruited to CD95 DISC. ${ }^{90}$ Furthermore, it can cleave Bid and activate the mitochondrial pathway in vitro. ${ }^{91}$ Caspase-10 has also been shown to sensitise cells to TRAIL-induced apoptosis. $^{92}$ Recently, caspase-10, along with caspase-8, was shown to be essential for mediating NF- $\kappa$ B-dependent inflammatory responses in antiviral signalling. ${ }^{93}$ Missense and inactivating mutations in casp10 gene have been reported to be associated with some cases of the autoimmune lymphoproliferative syndrome II (ALPS II), ${ }^{94}$ non-Hodgkin lymphoma ${ }^{95}$ and gastric cancer, ${ }^{96}$ however it is unclear whether these mutations directly contribute to the disease phenotype.

Caspase-2. Although caspase-2 was one of the first apoptotic caspases discovered, its physiological function remains a matter of considerable debate and somewhat of an enigma. Caspase-2 contains a CARD that facilitates dimerisation of procaspase-2 molecules, ${ }^{97,98}$ interaction with CARD-containing protein RAIDD ${ }^{99}$ or recruitment to large multiprotein complexes, ${ }^{100}$ events that trigger procaspase-2 activation. Caspase-2 is recruited into a protein complex similar to the Apaf-1/caspase-9 apoptosome. $^{101}$ The adaptor proteins RAIDD and PIDD have been identified as members of this large complex designated the 'PIDDosome'. ${ }^{101}$ An unusual feature of caspase- 2 is its localisation to the nucleus and the Golgi in addition to cytosol, although its protein targets in these compartments remain obscure. ${ }^{102-105}$ In some cells, caspase-2 was demonstrated to be required for mitochondrial outer membrane permeabilization (MOMP) and the release of apoptogenic factors in response to DNAdamaging agents. ${ }^{106}$ Caspase-2 has also been shown to be necessary for TRAIL-mediated, ${ }^{107,108}$ heat shock (HS)induced apoptosis, ${ }^{109,110}$ as well as oocyte cell death. ${ }^{11}$ Recently, caspase-2 was shown to associate with Fas/CD95 DISC and get activated in that complex, but apparently not required for CD95-induced cell death. ${ }^{112}$ Caspase-2 activation occurs rapidly and acute ablation of caspase- 2 in a multitude of cell lines inhibits apoptosis in response to a range of stimuli including anticancer drugs. ${ }^{106,113-120}$

Caspase-2 has also been shown to promote MAPK and NF$\kappa \mathrm{B}$ activation and may have some functions independent of its protease activity (see review by Lamkanfi et al. in this issue). Curiously, casp2-null mice develop normally with only minor apoptotic defects in some cell types, suggesting that the function of caspase-2 in developmental cell death and in the adult animal is either redundant, or compensated by other caspases in the $\mathrm{KO}$ animals. ${ }^{102,121}$ Cells derived from the casp2-deficient mice show normal sensitivity to many apoptotic stimuli. ${ }^{102,121}$ Recently Tu et al. reported that casp2 $-/-$ MEFs are resistant to apoptosis induced by HS. ${ }^{109}$ However, another study by Milleron and Bratton ${ }^{122}$ failed to see any role for caspase-2 in HS-induced MEF cell death. The phenotype of casp2/casp9 double $\mathrm{KO}$ is similar to casp9 $\mathrm{KO}$, suggesting that these two caspases are unlikely to be functionally redundant. ${ }^{77}$ Although some support for a compensatory pathway in casp2-deficient cells comes from a report where the authors found that in casp2-deficient neurons, the NGF-deprivation induced caspase-2-dependent cell death becomes dependent on the caspase- 9 pathway and casp2-null neurons show a three-fold compensatory elevation of caspase- 9 expression. ${ }^{123}$ Similar to the casp9-null thymocytes, the thymocytes derived from the casp2/casp9 double knockout (DKO) are normally sensitive to cell death, suggesting that in these cells these caspases do not 
compensate the loss of each other. ${ }^{77}$ Furthermore, B and $\mathrm{T}$ cells from the DKO mice are normally sensitivity to a variety of apoptotic stimuli including cytokine withdrawal and dexamethasone. ${ }^{77}$ These results suggest that caspase- 2 is not essential for most physiological cell death, or plays a redundant role in apoptosis. Another possibility is that caspase-2 is primarily required for executing apoptosis of aberrant cells (such as transformed cells).

The exact mechanism of caspase- 2 activation is still a matter of considerable debate. Some data suggest that dimerisation of caspase-2 molecules is sufficient to mediate its activation, and recruitment of caspase-2 to large apoptosome-like complexes, such as the PIDDosome, may facilitate caspase-2 dimerisation. ${ }^{98,101}$ It is possible that caspase-2 activation occurs by more than one mechanism. Recent data suggest that phosphorylation of caspase-2 at Ser157 by protein kinase CK2 (PKCK2) keeps it inactive. ${ }^{108}$ During TRAIL-mediated apoptosis, a lowering of PKCK2 levels results in dephosphorylation of caspase-2 that leads to caspase-2 dimerisation and activation in a PIDDosomeindependent manner. ${ }^{108}$ In Xenopus oocytes, CamKIImediated phosphorylation of caspase-2 appears to prevent its activation. ${ }^{111}$ These data are consistent with a model that predicts that the main event in caspase- 2 activation is precursor dimerisation that is prevented in healthy cells by phosphorylation of caspase-2. Whether this is a general mechanism of caspase-2 activation or limited to specific cell death signalling remains to be determined. Owing to many contradictory and confusing publications, it is unclear how active caspase-2 induces apoptosis. However, one plausible model is that caspase-2 cleaves and activates Bid, a BH3-only protein, which in turn engages the mitochondrial pathway to induce apoptosis. ${ }^{110}$

Caspase-3, -6 and -7 . Caspase-3 is the main downstream effector caspase that cleaves the majority of the cellular substrates in apoptotic cells. ${ }^{124}$ It is activated following cleavage by caspase- 8 or -9 , but not by caspase-2. ${ }^{8,9,124}$ Caspase-7 is highly similar to caspase- 3 and has similar substrate specificity. ${ }^{8,9}$ casp3 mutant mice in genetically mixed $129 / \mathrm{SvJ} \times \mathrm{C} 57 \mathrm{BL} / 6$ background die prenatally and show a phenotype somewhat similar to casp9 $\mathrm{KO}$ with hyperplasia of brain tissue. ${ }^{71}$ In these animals, reduced cell death and increased cell number in the central nervous system (CNS) of casp3-null animals becomes apparent by E12. Protrusions of the neuroepithelium in the retina are also visible due to reduced apoptosis. Cells derived from these animals show DNA fragmentation defects following treatment with cytotoxic agents, although most cells eventually die by apoptosis. ${ }^{71}$ However, in pure C57BL/6 background, casp3null animals are viable but show reduced fertility, suggesting that caspase- 3 is redundant for most developmental cell death. ${ }^{125}$ Casp7-null animals also develop normally and cells derived from these animals are sensitive to apoptosis induced by a range of agents. ${ }^{125}$ In C57BL/6 background, Casp3/Casp7 DKO mice die rapidly after birth but most animals show normal appearance. ${ }^{125}$ The DKO mice display defects in heart development. Additionally, the MEFs derived from DKO animals show resistance to apoptosis induced by UV, staurosporine, FasL and TNF, suggesting that combined function of caspase-3 and -7 is required for cell death execution. ${ }^{125}$ The DKO thymocytes show resistance to apoptosis induced via the intrinsic pathway (treatment with staurosporine and etoposide), but, interestingly, not to apoptosis induced by the death receptor pathway. The DKO cells also display delayed Bax translocation and cytochrome $c$ release from mitochondria, prompting the suggestion that caspase-3 and -7 function in amplifying mitochondrial caspase activation signalling. ${ }^{125}$

Although structurally similar to caspase-3 and -7, caspase6 has a somewhat different substrate specificity with optimal substrate being VEHD, rather than DEVD that is preferred by caspase- 3 and $-7 .^{126}$ The function of caspase- 6 remains a mystery as it does not seem to be essential for apoptosis induced by various agents. In earlier studies, caspase- 6 was shown to be required for the apoptotic cleavage of lamin A. ${ }^{127}$ However, caspase- $6 \mathrm{KO}$ mice develop normally ${ }^{128}$ and caspase-6-deficient DT40 chicken lymphoma cells are sensitive to killing by cytotoxic drugs. ${ }^{129}$

The caspase mutant and KO data suggest that while some caspases play essential roles in specific cell death pathways, others are either redundant, or compensated in the $\mathrm{KO}$ situations (Table 2). The studies also show that individual caspases may participate in apoptosis execution in a contextspecific manner.

\section{Regulators of Mammalian Caspases}

Given that active caspases execute cell dismantling, caspase activation is tightly regulated in various ways. Some of these regulatory mechanisms and caspase inhibitors are covered in a review by Callus and Vaux in this issue; however, caspase regulation by FLIP and the inhibitor of apoptosis proteins (IAPs) is worth a mention here given the important functions of these molecules in regulation of apoptosis. The gammaherpesvirus encodes V-FLIPs (viral FLICE-inhibitory proteins), which interfere with apoptosis signalling through the death receptors. ${ }^{130}$ The mammalian homologue of $v$-FLIP is cellular FLIP (cFLIP or FLIP). ${ }^{131,132}$ Both viral and cellular FLIPs contain two DEDs, which interact with the DED in FADD, thus inhibiting the recruitment and activation of caspase- 8 by TNFR family members. ${ }^{130-132}$ cFLIP is a key regulator of extrinsic pathway of caspase-8 activation. FLIP is upregulated by the NF- $\kappa \mathrm{B}$ pathway and this leads to cell survival in response to TNF. ${ }^{133}$ Recent data suggest that TNF $\alpha$-mediated JNK activation accelerates turnover of the NF- $\kappa$ B-induced FLIP. ${ }^{134}$ JNK acts via phosphorylation and activation of the ubiquitin ligase Itch, which then ubiquitinates FLIP, leading to its proteosomal degradation, thus sensitising cells to apoptosis. The flip KO mice die around E10.5 and, similar to fadd and casp8 KO, show impaired heart development. ${ }^{135}$ However, flip KO MEFs are highly sensitive to apoptosis induced by Fas ligand or TNF and show rapid caspase activation, suggesting that FLIP is necessary for protecting cells against caspase-8-mediated apoptosis mediated by TNFR family members. ${ }^{135}$

The mammalian IAP-like proteins include XIAP, clAP-1, cIAP-2, NAIP, ML-IAP, ILP-2 and survivin (reviewed by Callus and Vaux in this issue). Among these, only XIAP, C-IAP-1 and -2 can physically interact with caspases and inhibit mature 
caspase-3, -7 and $-9 .{ }^{57}$ However, only XIAP inhibits caspases at physiological concentrations. Structural studies suggest that the N-terminal BIR2 linker region of XIAP occupies the catalytic site in the active caspase- 3 and -7 , whereas the adjacent BIR2 may help to stabilise the interaction. ${ }^{57}$ In contrast, the XIAP BIR3 domain is required for inhibiting caspase-9. ${ }^{57}$ During apoptotic signaling, SMAC/DIABLO and $\mathrm{HtrA} 2$ are released from the mitochondria into the cytoplasm where they bind to XIAP and prevent its ability to inhibit caspase activity. ${ }^{136}$ Mature SMAC/HtrA2 contain the characteristic IAP-binding REAPER/HID/GRIM (RHG) motif present in Drosophila RPR, HID and GRIM that binds to the BIR domain of IAPS. Structual data show that the binding of SMAC to the BIR2 and BIR3 domains of XIAP disrupts its ability to inhibit the caspases by steric hindrance. ${ }^{136}$ Although the presence of IAPs and RHG (functional homologues of RPR, HID and GRIM) proteins in mammals suggest conserved mechanisms of caspase regulation, unlike in Drosophila, the function of these proteins in mammals does not appear to be essential for apoptosis regulation. The smac KO mice develop normally and smac-deficient cells are sensitive to apoptosis induced via both intrinsic and extrinsic pathways. ${ }^{137} \mathrm{HtrA} 2 \mathrm{KO}$ animals die around 30 days after birth owing to a neurodegenerative disorder, but cells derived from these animals fail to show any resistance to apoptosis. ${ }^{138}$ Combined deficiency of HtrA2 and SMAC leads to a phenotype similar to $\mathrm{HtrA} 2$ deficiency alone, suggesting that these two proteins are not compensating for each other. ${ }^{138}$ Xiap $\mathrm{KO}$ mice are also phenotypically normal and fail to show any defects in apoptosis. ${ }^{139}$ Although it is possible that in the absence of XIAP, SMAC and HtrA2, other yet unknown mechanisms can compensate for these proteins, the $\mathrm{KO}$ phenotypes suggest that these proteins are themselves not essential for developmental PCD. However, elevated levels of IAPs are often associated with resistance to apoptosis in human cancer cells and lowering IAPs using SMAC mimetics is known to sensitise cells to cytotoxic agents. ${ }^{140,141}$

\section{Perspectives}

It has been around 15 years since the first caspase was discovered. During this time, the pendulum has shifted from earlier predictions that all caspases play some role in the execution of apoptosis, to caspases may not be required for many forms cell deaths. The evolutionary conservation of caspases, and the fact that the loss of CED-3 (or its activator CED-4) results in a complete block in the developmental death of all somatic cells that are programmed to die, clearly suggest that caspases have evolved to be essential components of the cell death machinery. This concept is further supported by biochemical, cellular and genetic studies in Drosophila, where a single CED-3/caspase-9 homologue DRONC is essential for most developmental cell death and all stress-induced apoptosis. However, genetic and in vivo studies have also provided us the knowledge that some cell death and caspase activation can occur in the absence of DRONC, and apoptotic caspases can also function in some nonapoptotic pathways. Clearly, some caspases have no roles in apoptosis, some have both apoptotic and nonapoptotic functions, whereas others are primarily involved in executing apoptosis (see also other reviews in this issue). Based on C. elegans and fly studies one could argue that all apoptosis and most (if not all) developmental PCD require caspase function. It is probably the same in mammals, but mammals may have evolved alternative strategies to delete unwanted cells when caspases or caspase function is abrogated (such as in $\mathrm{KO}$ mice). These strategies may involve the alternate use of caspases or other pathways that are usually not involved in apoptosis.

A number of important issues and controversies remain unresolved in caspase biology. These include (but not limited to) (i) how to interpret and explain caspase redundancy and compensation in mammals and the $\mathrm{KO}$ phenotypes in mixed genetic backgrounds, (ii) how some caspases can function in both apoptotic and nonapoptotic pathways and factors that regulate the alternative caspase function, (iii) what pathways of caspase activation exist in the absence of initiator caspases, (iv) whether physiological cell death in the complete absence of caspases is indeed programmed or entirely different from apoptosis, (v) what caspase targets are essential for dismantling apoptotic cells and for the characteristic apoptotic phenotype and (vi) how precisely are caspases activated and regulated in response to different apoptotic and nonapoptotic signals. Hopefully, the ongoing genetic studies using various model systems and careful in vitro biochemical and molecular analyses coupled with more reliable reagents will help to explore the unresolved issues and clarify some of the controversies in the caspase field.

Acknowledgements. I thank the members of my laboratory for helpful comments. The caspase studies in my own laboratory are supported by the National Health and Medical Council of Australia and the Cancer Council of South Australia. I apologise to colleagues whose work could not be cited due to space constraints.

1. Thornberry NA, Bull HG, Calaycay JR, Chapman KT, Howard AD, Kostura MJ et al. (1992) A novel heterodimeric cysteine protease is required for interleukin-1 beta processing in monocytes. Nature 356: 768-774.

2. Cerretti DP, Kozlosky CJ, Mosley B, Nelson N, Van Ness K, Greenstreet TA et al. (1992) Molecular cloning of the interleukin-1 beta converting enzyme. Science 256: 97-100.

3. Yuan J, Shaham S, Ledoux S, Ellis HM, Horvitz HR (1993) The C. elegans cell death gene ced-3 encodes a protein similar to mammalian interleukin-1 beta-converting enzyme. Cell 75: 641-652.

4. Miura M, Zhu H, Rotello R, Hartwieg EA, Yuan J (1993) Induction of apoptosis in fibroblasts by IL- 1 beta-converting enzyme, a mammalian homolog of the $C$. elegans cell death gene ced-3. Cell 75: 653-660.

5. Kumar S, Tomooka Y, Noda M (1992) Identification of a set of genes with developmentally down-regulated expression in the mouse brain. Biochem Biophys Res Commun 185: 1155-1161.

6. Kumar S, Kinoshita M, Noda M, Copeland NG, Jenkins NA (1994) Induction of apoptosis by mouse Nedd2 gene, which encodes a protein similar to the product of the Caenorhabditis elegans cell death gene ced-3 and the mammalian IL-1 $\beta$-converting enzyme. Genes Dev 8: 1613-1626.

7. Lamkanfi M, Declercq W, Kalai M, Saelens X, Vandenabeele P (2002) Alice in caspase land. A phylogenetic analysis of caspases from worm to man. Cell Death Differ 9: 358361.

8. Fuentes-Prior P, Salvesen GS (2004) The protein structures that shape caspase activity, specificity, activation and inhibition. Biochem $\mathrm{J}$ 384: 201-232.

9. Degterev A, Boyce M, Yuan J (2003) A decade of caspases. Oncogene 22: 8543-8567.

10. Ellis HM, Horvitz HR (1986) Genetic control of programmed cell death in the nematode $C$. elegans. Cell 44: 817-829.

11. Shaham S (1998) Identification of multiple Caenorhabditis elegans caspases and their potential roles in proteolytic cascades. J Biol Chem 273: 35109-35117.

12. Lettre G, Hengartner MO (2006) Developmental apoptosis in C. elegans: a complex CEDnario. Nat Rev Mol Cell Biol 7: 97-108. 
13. Yan N, Chai J, Lee ES, Gu L, Liu Q, He J et al. (2005) Structure of the CED-4-CED-9 complex provides insights into programmed cell death in Caenorhabditis elegans. Nature 437: 831-837.

14. Song Z, McCall K, Steller H (1997) DCP-1, a Drosophila cell death protease essential for development. Science 275: 536-540.

15. Chen P, Rodriguez A, Erskine R, Thach T, Abrams JM (1998) Dredd, a novel effector of the apoptosis activators reaper, grim and hid in Drosophila. Dev Bio 201: 202-216.

16. Fraser AG, Evan GI (1997) Identification of a Drosophila melanogaster ICE/CED-3 related protease, drICE. EMBO J 16: 2805-2813.

17. Dorstyn L, Colussi PA, Quinn LM, Richardson H, Kumar S (1999) DRONC, a nove ecdysone-inducible Drosophila caspase. Proc Natl Acad Sci USA 96: 4307-4312.

18. Dorstyn L, Read SH, Quinn LM, Richardson H, Kumar S (1999) DECAY, a nove Drosophila caspase related to mammalian caspase-3 and caspase-7. J Biol Chem 274: 30778-30783.

19. Harvey NL, Daish T, Mills K, Dorstyn L, Quinn LM, Read SH et al. (2001) Characterization of the Drosophila caspase, DAMM. J Biol Chem 276: 25342-25350.

20. Doumanis J, Quinn L, Richardson H, Kumar S (2001) STRICA, a novel Drosophila caspase with an unusual serine/threonine-rich prodomain, interacts with DIAP1 and DIAP2. Cell Death Diff 8: 387-394.

21. Kumar S, Doumanis J (2000) The fly caspases. Cell Death Diff 7: 1039-1044

22. Leulier F, Rodriguez A, Khush RS, Abrams JM, Lemaitre B (2000) The Drosophila caspase Dredd is required to resist gram-negative bacterial infection. EMBO Rep 1: 353358.

23. Hu S, Yang X (2000) dFADD, a novel death domain-containing adapter protein for the Drosophila caspase DREDD. J Biol Chem 275: 30761-30764.

24. Zhou R, Silverman N, Hong M, Liao DS, Chung Y, Chen ZJ et al. (2005) The role of ubiquitination in Drosophila innate immunity. J Biol Chem 280: 34048-34055.

25. Huh JR, Vernooy SY, Yu H, Yan N, Shi Y, Guo M et al. (2004) Multiple apoptotic caspase cascades are required in nonapoptotic roles for Drosophila spermatid individualization. PLoS Biol 2: E15.

26. Daish TJ, Mills K, Kumar S (2004) Drosophila caspase DRONC is required for specific developmental cell death pathways and stress-induced apoptosis. Dev Cell 7: 909-915.

27. Chew SK, Akdemir F, Chen P, Lu WJ, Mills K, Daish T et al. (2004) The apical caspase dronc governs programmed and unprogrammed cell death in Drosophila. Dev Cell 7 897-907.

28. Xu D, Li Y, Arcaro M, Lackey M, Bergmann A (2005) The CARD-carrying caspase Dronc is essential for most, but not all, developmental cell death in Drosophila. Developmen 132: 2125-2134.

29. Waldhuber M, Emoto K, Petritsch C (2005) The Drosophila caspase DRONC is required for metamorphosis and cell death in response to irradiation and developmental signals. Mech Dev 122: 914-927.

30. Kondo S, Senoo-Matsuda N, Hiromi Y, Miura M (2006) DRONC coordinates cell death and compensatory proliferation. Mol Cell Biol 26: 7258-7268.

31. Mills K, Daish T, Kumar S (2005) The function of the Drosophila caspase DRONC in cell death and development. Cell Cycle 4: 744-746.

32. Kumar S (2004) Migrate, differentiate, proliferate, or die: pleiotropic functions of an apical 'apoptotic caspase'. Sci STKE 2004: pe49.

33. Meier P, Silke J, Leevers SJ, Evan GI (2000) The Drosophila caspase DRONC is regulated by DIAP1. EMBO J 19: 598-611.

34. Quinn LM, Dorstyn L, Mills K, Colussi PA, Chen P, Coombe M et al. (2000) An essential role for the caspase Dronc in developmentally programmed cell death in Drosophila. J Biol Chem 275: 40416-40424.

35. Hawkins CJ, Yoo SJ, Peterson EP, Wang SL, Vernooy SY, Hay BA (2000) The Drosophila caspase Dronc cleaves following glutamate or aspartate and is regulated by Diap1, Hid and Grim. J Biol Chem 275: 27084-27093.

36. Leulier F, Ribeiro PS, Palmer E, Tenev T, Takahashi K, Robertson D et al. (2006) Systematic in vivo RNAi analysis of putative components of the Drosophila cell death machinery. Cell Death Differ 13: 1663-1674.

37. Cakouros D, Daish T, Martin D, Baehrecke EH, Kumar S (2002) Ecdysone-induced expression of the caspase DRONC during hormone dependent programmed cell death in Drosophila is regulated by Broad-Complex. J Cell Biol 157: 985-995.

38. Cakouros D, Daish TJ, Kumar S (2004) Ecdysone receptor directly binds the promoter of the Drosophila caspase dronc regulating its expression in specific tissues. J Cell Biol 165 $631-640$.

39. Cakouros D, Daish TJ, Mills K, Kumar S (2004) An arginine-histone methyl transferase, CARMER, coordinates ecdysone-mediated apoptosis in Drosophila cells. J Biol Chem 279: 18467-18471

40. Daish T, Cakouros D, Kumar S (2003) Distinct promoter regions regulate spatial and temporal expression of the Drosophila caspase dronc. Cell Death Differ 10: 1348-1356.

41. Kumar S, Cakouros D (2004) Transcriptional control of the core cell death machinery Trends Biochem Sci 29: 193-199.

42. Dorstyn L, Read S, Cakouros D, Huh JR, Hay BA, Kumar S (2002) The role of cytochrome $c$ in caspase activation in Drosophila cells. J Cell Biol 156: 1089-1098.

43. Kuranaga E, Kanuka H, Tonoki A, Takemoto K, Tomioka T, Kobayashi M et al. (2006) Drosophila IKK-related kinase regulates nonapoptotic function of caspases via degradation of IAPs. Cell 126: 583-596.
44. Muro I, Berry DL, Huh JR, Chen $\mathrm{CH}$, Huang H, Yoo SJ et al. (2006) The Drosophila caspase Ice is important for many apoptotic cell deaths and for spermatid individualization, a nonapoptotic process. Development 133: 3305-3315.

45. Xu D, Wang Y, Willecke R, Chen Z, Ding T, Bergmann A (2006) The effector caspases $\mathrm{drICE}$ and $\mathrm{dcp}-1$ have partially overlapping functions in the apoptotic pathway in Drosophila. Cell Death Differ 13: 1697-1706.

46. Kilpatrick ZE, Cakouros D, Kumar S (2005) Ecdysone-mediated up-regulation of the effector caspase DRICE is required for hormone-dependent apoptosis in Drosophila cells. $J$ Biol Chem 280: 11981-11986.

47. Fraser AG, McCarthy NJ, Evan GI (1997) drICE is an essential caspase required for apoptotic activity in Drosophila cells. EMBO J 16: 6192-6199.

48. Enari M, Sakahira H, Yokoyama H, Okawa K, Iwamatsu A, Nagata S (1998) A caspase activated DNase that degrades DNA during apoptosis, and its inhibitor ICAD. Nature 391: 43-50.

49. Yokoyama H, Mukae N, Sakahira H, Okawa K, Iwamatsu A, Nagata S (2000) A novel activation mechanism of caspase-activated DNase from Drosophila melanogaster. J Biol Chem 275: 12978-12986.

50. McCall K, Steller H (1998) Requirement for DCP-1 caspase during Drosophila oogenesis. Science 279: 230-234.

51. Laundrie B, Peterson JS, Baum JS, Chang JC, Fileppo D, Thompson SR et al. (2003) Germline cell death is inhibited by P-element insertions disrupting the dcp-1/pita nested gene pair in Drosophila. Genetics 165: 1881-1888.

52. Lee CY, Clough EA, Yellon P, Teslovich TM, Stephan DA, Baehrecke EH (2003) Genome-wide analyses of steroid- and radiation-triggered programmed cell death in Drosophila. Curr, Biol 13: 350-357.

53. Wang SL, Hawkins CJ, Yoo SJ, Muller HA, Hay BA (1999) The Drosophila caspase inhibitor DIAP1 is essential for cell survival and is negatively regulated by HID. Cell 98: 453-463.

54. Goyal L, McCall K, Agapite J, Hartwieg E, Steller H (2000) Induction of apoptosis by Drosophila reaper, hid and grim through inhibition of IAP function. EMBO $J 19$ : 589-597.

55. Colussi PA, Quinn LM, Huang DCS, Coombe M, Read SH, Richardson H et al. (2000) Debcl, a pro-apoptotic Bcl-2 homologue, is a component of the Drosophila cell death machinery. J Cell Biol 148: 703-714.

56. Quinn L, Coomb M, Mills K, Daish T, Colussi P, Kumar S et al. (2003) Buffy, a Drosophila $\mathrm{Bcl}-2$ related protein, has anti-apoptotic and cell cycle inhibitory function. EMBO J 22 . 3568-3579.

57. Vaux DL, Silke J (2005) IAPs, RINGs and ubiquitylation. Nat Rev Mol Cell Biol 6: 287-297.

58. Li P, Nijhawan D, Budihardjo I, Srinivasula SM, Ahmad M, Alnemri ES et al. (1997) Cytochrome $c$ and dATP-dependent formation of Apaf1/caspase- 9 complex initiates the apoptotic protease cascade. Cell 91: 479-489.

59. Dorstyn L, Kumar S (2006) A cytochrome c-free fly apoptosome. Cell Death Differ 13: 1049-1051.

60. Mills K, Daish T, Harvey KF, Pfleger CM, Hariharan IK, Kumar S (2006) The Drosophila melanogaster Apaf-1 homologue ARK is required for most, but not all, programmed cell death. J Cell Biol 172: 809-815.

61. Srivastava M, Scherr H, Lackey M, Xu D, Chen Z, Lu J et al. (2006) ARK, the Apaf-1 related killer in Drosophila, requires diverse domains for its apoptotic activity. Cell Death Differ (in press).

62. Akdemir F, Farkas R, Chen P, Juhasz G, Medved'ova L, Sass M et al. (2006) Autophagy occurs upstream or parallel to the apoptosome during histolytic cell death. Development 133: $1457-1465$.

63. Varkey J, Chen P, Jemmerson R, Abrams JM (1999) Altered cytochrome $c$ display precedes apoptotic cell death in Drosophila. J Cell Biol 144: 701-710.

64. Zimmermann KC, Ricci JE, Droin NM, Green DR (2002) The role of ARK in stressinduced apoptosis in Drosophila cells. J Cell Biol 156: 1077-1087.

65. Dorstyn L, Mills K, Lazebnik Y, Kumar S (2004) The two cytochrome c species, DC3 and DC4, are not required for caspase activation and apoptosis in Drosophila cells. J Cell Biol 167: $405-410$.

66. Means JC, Muro I, Clem RJ (2006) Lack of involvement of mitochondria factors in caspase activation in a Drosophila cell-free system. Cell Death Differ 13: $1222-1234$.

67. Yu X, Wang L, Acehan D, Wang X, Akey CW (2006) Three-dimensional structure of a double apoptosome formed by the Drosophila Apaf-1 related killer. J Mol Biol 355: 577589 .

68. Acehan D, Jiang X, Morgan DG, Heuser JE, Wang X, Akey CW (2002) Three-dimensional structure of the apoptosome. Implications for assembly, procaspase- 9 binding, and activation. Mol Cell 9: 423-432.

69. Hakem R, Hakem A, Duncan GS, Henderson JT, Woo M, Soengas MS et al. (1998) Differential requirement for caspase-9 in apoptotic pathways in vivo. Cell 94: 339-352.

70. Kuida K, Haydar TF, Kuan C-Y, Gu Y, Taya C, Karasuyama H et al. (1998) Reduced apoptosis and cytochrome $c$-mediated caspase activation in mice lacking caspase 9. Cell 94: 325-337.

71. Kuida K, Zheng TS, Na S, Kuan C, Yang D, Karasuyama H et al. (1996) Decreased apoptosis in the brain and premature lethality in CPP32-deficient mice. Nature 384: 368-372. 
72. Cecconi F, Alvarez-Bolado G, Meyer BI, Roth KA, Gruss $P$ (1998) Apaf1 (CED-4 homolog) regulates programmed cell death in mammalian development. Cell 94: 727-737.

73. Yoshida H, Kong YY, Yoshida R, Elia AJ, Hakem A, Hakem R et al. (1998) Apaf1 is required for mitochondrial pathways of apoptosis and brain development. Cell 94: 739-750

74. Honarpour N, Du C, Richardson JA, Hammer RE, Wang X, Herz J (2000) Adult Apaf-1deficient mice exhibit male infertility. Dev Biol 218: 248-258.

75. Okamoto H, Shiraishi $\mathrm{H}$, Yoshida $\mathrm{H}$ (2006) Histological analyses of normally grown, fertile Apaf1-deficient mice. Cell Death Differ 13: 668-671.

76. Marsden VS, O'Connor L, O'Reilly LA, Silke J, Metcalf D, Ekert PG et al. (2002) Apoptosis initiated by Bcl-2-regulated caspase activation independently of the cytochrome $c / A p a f-1 /$ caspase-9 apoptosome. Nature 419: 634-637.

77. Marsden VS, Ekert PG, Van Delft M, Vaux DL, Adams JM, Strasser A (2004) Bcl-2 regulated apoptosis and cytochrome $c$ release can occur independently of both caspase2 and caspase-9. J Cell Biol 165: 775-780.

78. Ekert PG, Read SH, Silke J, Marsden VS, Kaufmann H, Hawkins CJ et al. (2004) Apaf-1 and caspase-9 accelerate apoptosis, but do not determine whether factor-deprived or drug-treated cells die. J Cell Biol 165: 835-842.

79. Baliga C, Kumar S (2003) The Apaf-1/cytochrome $c$ apoptosome: an essential initiator of caspase activation or just a sideshow? Cell Death Differ 10: 15-17.

80. Hao Z, Duncan GS, Chang CC, Elia A, Fang M, Wakeham A et al. (2005) Specific ablation of the apoptotic functions of cytochrome $c$ reveals a differential requirement for cytochrome $c$ and Apaf-1 in apoptosis. Cell 121: 579-591.

81. Boldin MP, Goncharov TM, Goltsev YV, Wallach D (1996) Involvement of MACH, a nove Mort1/FADD-interacting protease, in Fas/APO1- and TNF receptor-induced cell death. Cell 85: 803-815.

82. Muzio M, Chinnaiyan AM, Kischkel FC, O'Rourke $K$, Shevchenko A, Scaffidi $C$ et al. (1996) FLICE, a novel FADD-homologous ICE/CED-3-like protease, is recruited to the CD95 (Fas/APO-1) death-inducing signaling complex. Cell 85: 817-827.

83. Varfolomeev EE, Schuchmann M, Luria V, Chiannilkulchai N, Beckmann JS Mett IL et al. (1998) Targeted disruption of the mouse caspase 8 gene ablates cell death induction by the TNF receptors, Fas/Apo1, and DR3 and is lethal prenatally. Immunity 9: 267-276.

84. Kang TB, Ben-Moshe T, Varfolomeev EE, Pewzner-Jung Y, Yogev N, Jurewicz A et al (2004) Caspase-8 serves both apoptotic and nonapoptotic roles. J Immunol 173: 2976 2984

85. Chun HJ, Zheng L, Ahmad M, Wang J, Speirs CK, Siegel RM et al. (2002) Pleiotropic defects in lymphocyte activation caused by caspase- 8 mutations lead to human immunodeficiency. Nature 419: 395-399.

86. Yeh WC, de la Pompa JL, McCurrach ME, Shu H-B, Elia AJ, Shahinian A et al. (1998) FADD: essential for embryo development and signaling from some, but not all, inducers of apoptosis. Science 279: 1954-1958

87. Zhang J, Cado D, Kabra NH, Winoto A (1998) Fas-mediated apoptosis and activation-induced T-cell proliferation are defective in mice lacking FADD/MORT1. Nature 392: 296-299.

88. Kabra NH, Kang C, Hsing LC, Zhang J, Winoto A (2001) T cell-specific FADD-deficien mice: FADD is required for early T cell development. Proc Natl Acad Sci USA 98: 63076312.

89. Zhang Y, Rosenberg S, Wang H, Imtiyaz HZ, Hou YJ, Zhang J (2005) Conditional Fasassociated death domain protein (FADD): GFP knockout mice reveal FADD is dispensable in thymic development but essential in peripheral $\mathrm{T}$ cell homeostasis. J Immunol 175: 3033-3044.

90. Kischkel FC, Lawrence DA, Tinel A, LeBlanc H, Virmani A, Schow P et al. (2001) Death receptor recruitment of endogenous caspase-10 and apoptosis initiation in the absence of caspase-8. J Biol Chem 276: 46639-46646.

91. Milhas D, Cuvillier O, Therville N, Clave P, Thomsen M, Levade T et al. (2005) Caspase10 triggers Bid cleavage and caspase cascade activation in FasL-induced apoptosis. J Biol Chem 280: 19836-19842.

92. Engels IH, Totzke G, Fischer U, Schulze-Osthoff K, Janicke RU (2005) Caspase-10 sensitizes breast carcinoma cells to TRAlL-induced but not tumor necrosis factor-induced apoptosis in a caspase-3-dependent manner. Mol Cell Biol 25: 2808-2818.

93. Takahashi K, Kawai T, Kumar H, Sato S, Yonehara S, Akira S (2006) Roles of caspase-8 and caspase-10 in innate immune responses to double-stranded RNA. J Immunol 176: $4520-4524$.

94. Zhu S, Hsu AP, Vacek MM, Zheng L, Schaffer AA, Dale JK et al. (2006) Genetic alterations in caspase-10 may be causative or protective in autoimmune lymphoproliferative syndrome. Hum Genet 119: 284-294.

95. Shin MS, Kim HS, Kang CS, Park WS, Kim SY, Lee SN et al. (2002) Inactivating mutations of CASP10 gene in non-Hodgkin lymphomas. Blood 99: 4094-4099.

96. Park WS, Lee JH, Shin MS, Park JY, Kim HS, Lee JH et al. (2002) Inactivating mutations of the caspase-10 gene in gastric cancer. Oncogene 21: 2919-2925.

97. Butt AJ, Harvey NL, Parasivam G, Kumar S (1998) Dimerization and autoprocessing of the Nedd2(caspase-2) precursor requires both the prodomain and the carboxyl-terminal regions. J Biol Chem 273: 6763-6768.

98. Baliga BC, Read SH, Kumar S (2004) The biochemical mechanism of caspase-2 activation. Cell Death Differ 11: 1234-1241.
99. Shearwin-Whyatt LM, Harvey NL, Kumar S (2000) Subcellular localization and CARD-dependent oligomerization of the death adaptor RAIDD. Cell Death Diff 7 155-165.

100. Read SH, Baliga BB, Ekert P, Vaux DL, Kumar S (2002) A novel Apaf-1-independent putative caspase-2 activation complex. J Cell Biol 159: 739-745.

101. Tinel A, Tschopp J (2004) The PIDDosome, a protein complex implicated in activation of caspase-2 in response to genotoxic stress. Science 304: 843-846.

102. O'Reilly LA, Ekert P, Harvey N, Marsden V, Cullen L, Vaux DL et al. (2002) Caspase-2 is not required for thymocyte or neuronal apoptosis even though cleavage of caspase-2 is mediated by Apaf-1 and caspase-9. Cell Death Diff 9: 832-841.

103. Colussi PA, Harvey NL, Kumar S (1998) Prodomain-dependent nuclear localization of the caspase-2(Nedd2) precursor. J Biol Chem 273: 24535-24542.

104. Mancini M, Machamer CE, Roy S, Nicholson DW, Thornberry NA, Casciola-Rosen LA et al. (2000) Caspase-2 is localized at the Golgi complex and cleaves golgin-160 during apoptosis. J Cell Biol 149: 603-612.

105. Baliga BC, Colussi PA, Read SH, Dias MM, Jans DA, Kumar S (2003) Role of prodomain in importin-mediated nuclear localization and activation of caspase-2. J Biol Chem $\mathbf{2 7 8}$ 4899-4905.

106. Zhivotovsky B, Orrenius S (2005) Caspase-2 function in response to DNA damage. Biochem Biophys Res Commun 331: 859-867.

107. Wagner KW, Engels IH, Deveraux QL (2004) Caspase-2 can function upstream of bid cleavage in the TRAIL apoptosis pathway. J Biol Chem 279: 35047-35052.

108. Shin S, Lee Y, Kim W, Ko H, Choi H, Kim K (2005) Caspase-2 primes cancer cells for TRAlL-mediated apoptosis by processing procaspase-8. EMBO J 24: 3532-3542.

109. Tu S, McStay GP, Boucher LM, Mak T, Beere HM, Green DR (2006) In situ trapping of activated initiator caspases reveals a role for caspase-2 in heat shock-induced apoptosis. Nat Cell Biol 8: 72-77.

110. Bonzon C, Bouchier-Hayes L, Pagliari LJ, Green DR, Newmeyer DD (2006) Caspase-2 induced apoptosis requires bid cleavage: a physiological role for bid in heat shockinduced death. Mol Biol Cell 17: 2150-2157.

111. Nutt LK, Margolis SS, Jensen M, Herman CE, Dunphy WG, Rathmell JC et al. (2005) Metabolic regulation of oocyte cell death through the CaMKII-mediated phosphorylation of caspase-2. Cell 123: 89-103.

112. Lavrik IN, Golks A, Baumann S, Krammer PH (2006) Caspase-2 is activated at the CD95 death-inducing signaling complex in the course of CD95-induced apoptosis. Blood 108 $559-565$

113. Harvey NL, Butt A, Kumar S (1997) Functional activation of Nedd2/ICH-1 (caspase-2) is an early process in apoptosis. J Biol Chem 272: 13134-13139.

114. Kumar S (1995) Inhibition of apoptosis by antisense Nedd2 expression. FEBS Lett 368 : 69-72.

115. Guo Y, Srinivasula SM, Druilhe A, Fernandes-Alnemri T, Alnemri ES (2002) Caspase-2 induces apoptosis by releasing proapoptotic proteins from mitochondria. J Biol Chem 277 13430-13437

116. Troy CM, Shelanski ML (2003) Caspase-2 redux. Cell Death Differ 10: 101-107.

117. Paroni G, Henderson C, Schneider C, Brancolini C (2002) Caspase-2 can trigger cytochrome $c$ release and apoptosis from the nucleus. J Biol Chem 277: 15147-15161.

118. Colussi PA, Harvey NL, Shearwin-Whyatt LM, Kumar S (1998) Conversion of procaspase- 3 to an autoactivating caspase by fusion to the caspase-2 prodomain J Biol Chem 273: 26566-26570.

119. Lassus $P$, Opitz-Araya $X$, Lazebnik $Y$ (2002) Requirement for caspase-2 in stress-induced apoptosis before mitochondrial permeabilization. Science 297: 1352-1354.

120. Robertson JD, Enoksson M, Suomela M, Zhivotovsky B, Orrenius S (2002) Caspase-2 acts upstream of mitochondria to promote cytochrome $c$ release during etoposideinduced apoptosis. J Biol Chem 277: 29803-29809.

121. Bergeron L, Perez Gl, Macdonald G, Shi L, Sun Y, Jurisicova A et al. (1998) Defects in regulation of apoptosis in caspase-2-deficient mice. Genes Dev 12: 1304-1314.

122. Milleron RS, Bratton SB (2006) Heat shock induces apoptosis independently of any known initiator caspase-activating complex. J Biol Chem 281: 16991-17000.

123. Troy CM, Rabacchi SA, Hohl JB, Angelastro JM, Greene LA, Shelanski ML (2001) Death in the balance: alternative participation of the caspase-2 and -9 pathways in neuronal death induced by nerve growth factor deprivation. J Neurosci 21: 5007-5016.

124. Porter AG, Janicke RU (1999) Emerging roles of caspase-3 in apoptosis. Cell Death Diffe 6: $99-104$.

125. Lakhani SA, Masud A, Kuida K, Porter Jr GA, Booth CJ, Mehal WZ et al. (2006) Caspases 3 and 7: key mediators of mitochondrial events of apoptosis. Science 311: 847-851.

126. Thornberry NA, Rano TA, Peterson EP, Rasper DM, Timkey T, Garcia-Calvo $M$ et al. (1997) A combinatorial approach defines specificities of members of the caspase family and granzyme B. Functional relationships established for key mediators of apoptosis. J Biol Chem 272: 17907-17911.

127. Takahashi A, Alnemri ES, Lazebnik YA, Fernandes-Alnemri T, Litwack G, Moir RD et al. (1996) Cleavage of lamin A by Mch2 alpha but not CPP32: multiple interleukin 1 betaconverting enzyme-related proteases with distinct substrate recognition properties are active in apoptosis. Proc Natl Acad Sci USA 93: 8395-8400.

128. Zheng TS, Hunot S, Kuida K, Flavell RA (1999) Caspase knockouts: matters of life and death. Cell Death Differ 6: 1043-1053.

129. Loegering DA, Ruchaud S, Earnshaw WC, Kaufmann SH (2006) Evaluation of the role of caspase-6 in anticancer drug-induced apoptosis. Cell Death Differ 13: 346-347. 
130. Thome M, Schneider P, Hofmann K, Fickenscher H, Mein E, Neipel F et al. (1997) Viral FLICEinhibitory proteins (FLIPs) prevent apoptosis induced by death receptors. Nature 386: 517-521.

131. Irmler M, Thome M, Hahne M, Schneider P, Hofmann K, Steiner V et al. (1997) Inhibition of death receptor signals by cellular FLIP. Nature 388: 190-195.

132. Thome M, Tschopp J (2001) Regulation of lymphocyte proliferation and death by FLIP. Nat Rev Immunol 1: 50-58.

133. Micheau O, Tschopp J (2003) Induction of TNF receptor I-mediated apoptosis via two sequential signaling complexes. Cell 114: 181-190.

134. Chang L, Kamata H, Solinas G, Luo JL, Maeda S, Venuprasad K et al. (2006) The E3 ubiquitin ligase itch couples JNK activation to TNFalpha-induced cell death by inducing c-FLIP(L) turnover. Cell 124: 601-613.

135. Yeh WC, Itie A, Elia AJ, Ng M, Shu HB, Wakeham A et al. (2000) Requirement for Caspe (c-FLIP) in regulation of death receptor-induced apoptosis and embryonic development. Immunity 12: 633-642.
136. Vaux DL, Silke J (2003) Mammalian mitochondrial IAP binding proteins. Biochem Biophys Res Commun 304: 499-504.

137. Okada H, Suh WK, Jin J, Woo M, Du C, Elia A et al. (2002) Generation and characterization of Smac/DIABLO-deficient mice. Mol Cell Biol 22: 35093517.

138. Martins LM, Morrison A, Klupsch K, Fedele V, Moisoi N, Teismann P et al. (2004) Neuroprotective role of the Reaper-related serine protease HtrA2/Omi revealed by targeted deletion in mice. Mol Cell Biol 24: 9848-9862.

139. Harlin H, Reffey SB, Duckett CS, Lindsten T, Thompson CB (2001) Characterization of XIAP-deficient mice. Mol Cell Biol 21: 3604-3608.

140. Beauparlant $P$, Shore GC (2003) Therapeutic activation of caspases in cancer: a question of selectivity. Curr Opin Drug Discov Devel 6: 179-187.

141. Schimmer AD, Dalili S, Batey RA, Riedl SJ (2006) Targeting XIAP for the treatment of malignancy. Cell Death Differ 13: 179-188. 